\title{
Interlibrary Loan Purchase-on-demand: A Misleading Literature
}

Gerrit van Dyk

gerrit_vandyk@byu.edu

Follow this and additional works at: https://scholarsarchive.byu.edu/facpub

Part of the Collection Development and Management Commons

\section{Original Publication Citation}

Library Collections, Acquisitions and Technical Services

\section{BYU ScholarsArchive Citation}

van Dyk, Gerrit, "Interlibrary Loan Purchase-on-demand: A Misleading Literature" (2011). Faculty Publications. 85.

https://scholarsarchive.byu.edu/facpub/85 


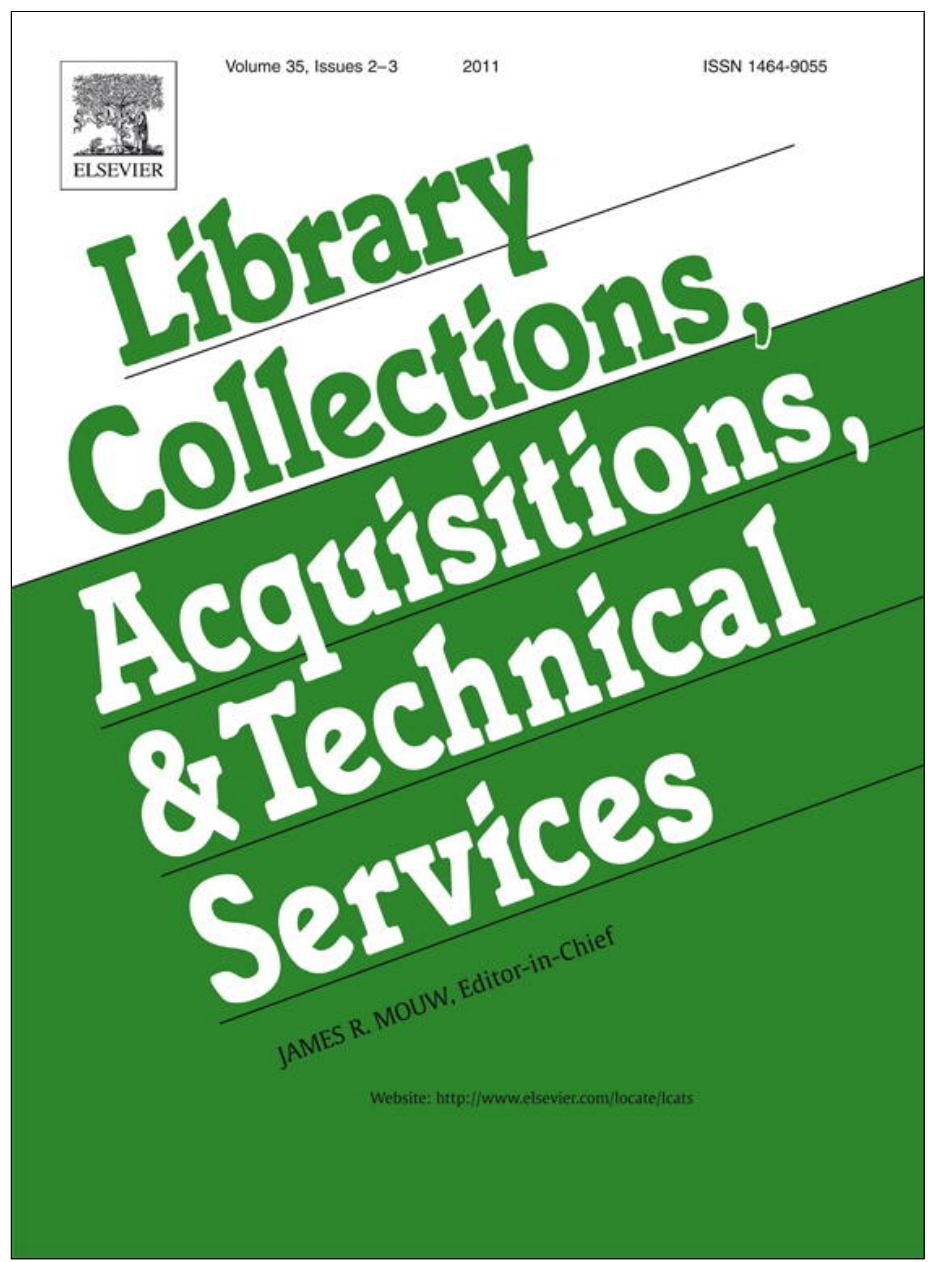

This article appeared in a journal published by Elsevier. The attached copy is furnished to the author for internal non-commercial research and education use, including for instruction at the authors institution and sharing with colleagues.

Other uses, including reproduction and distribution, or selling or licensing copies, or posting to personal, institutional or third party websites are prohibited.

In most cases authors are permitted to post their version of the article (e.g. in Word or Tex form) to their personal website or institutional repository. Authors requiring further information regarding Elsevier's archiving and manuscript policies are encouraged to visit:

http://www.elsevier.com/copyright 


\title{
Interlibrary loan purchase-on-demand: A misleading literature
}

\author{
Gerrit van Dyk* \\ Brigham Young University, 3427 Harold B. Lee Library, Provo, UT 84602, USA
}

\section{A R T I C L E I N F O}

Available online 26 May 2011

\section{Keywords:}

Purchase-on-demand

Patron-driven acquisitions

Interlibrary loan

Cost-per-use

Libraries

\begin{abstract}
A B S T R A C T
Many libraries are engaging in interlibrary loan purchase-on-demand without fully acknowledging all of the costs of adding such titles to their collections. This study compares the costs of monograph interlibrary loans and the costs of monograph accession, including staffing overhead costs for both. In order to be truly cost-effective, interlibrary loan purchaseon-demand titles must have a minimum projected circulation, depending on the base price to purchase the item. A review of current patron-driven acquisitions models associated with interlibrary loan purchase-on-demand is included.
\end{abstract}

(c) 2011 Elsevier Ltd. All rights reserved.

Over the past two decades the concept of purchase-on-demand (POD) has blossomed in library literature. With the painful reduction in library budgets since the 1990s, the "just-in-case" acquisitions model is not enough to justify purchasing titles that do not get used. "Just-in-time" models try to balance the needs of the patrons with the budgets of the librarians.

Since the turn of the millennium patron-driven acquisitions models based on interlibrary loan (ILL) usage and requests have likewise increased and received considerable attention. However, there has yet to be a comprehensive study of the costs associated with these programs contrasted with the cost of ILL. While it is easy to focus on the seemingly astronomical cost of one ILL request estimated near $\$ 27.00$ (Jackson, 2004), advocates of the "buy instead of borrow" trend overlook what that ILL cost actually includes and in some cases fail to calculate corresponding costs for purchasing instead of borrowing. Librarians need to be aware of all of the costs to conduct ILL POD programs, not just the raw cost to purchase a title and have it shipped to their library.

\section{Why buy?}

In 2004 the Association of Research Libraries (ARL) published the most recent cost study for mediated ILL borrowing costs (Jackson, 2004). Borrowing designates the process in which a librarian asks another library to supply an item which is not owned or is otherwise unavailable at the requesting librarian's library. The term "mediated" describes a transaction which a librarian must "touch" or edit in order for the patron to receive the requested item. For items that a librarian must request from another library, the total mean cost per ILL transaction is $\$ 17.50$ (Jackson, 2004, p. 31). For items that are lent to another library, the total mean cost per ILL transaction is $\$ 9.27$ (Jackson, 2004, p. 31). Thus, the total mean cost of an ILL transaction from start to finish is $\$ 26.77$, a significantly high enough number that librarians have questioned the validity of turning to ILL as often as they have in the past.

Brucknell University's Perdue and Van Fleet (1999) are widely cited because of their pioneering work and compelling findings regarding ILL POD. By June 1994, items purchased during the fiscal year 1990-1991 by Brucknell University from ILL requests circulated almost twice as many times as those purchased by firm order during the same period (p. 24). Perdue and Van Fleet (1999) further report that "[d]uring the 1996/97 fiscal year, the average cost of an ILL book purchase was $\$ 37.30$, compared to $\$ 33.85$ for firm order and approval books" (p. 26). However, based on the number of times the items were circulated, their costper-use (CPU) of these same items was $\$ 22.74$. For items purchased in $1990 / 91$, the CPU was only $\$ 7.48$, a number considerably smaller than the mean cost of a borrowing ILL transaction (\$17.50). Perdue and Van Fleet (1999) acknowledge that this \$7.48 is based solely on the cost to purchase the book and does not include the cost to acquire, catalog, label, or shelve it (p. 23).

\footnotetext{
* Corresponding author.

E-mail address: gerrit_vandyk@byu.edu.
} 
Purdue University conducted a study in which they had subject selectors review ILL POD items to determine their scholarly value (Anderson et al., 2002). An unexpected byproduct of their study showed that many of the titles acquired through ILL POD were of interdisciplinary nature, items that crossed multiple subject selectors' collections and had been difficult to assign to a specific budget in the past. Although CPU and the total cost of a book including staffing overhead were not examined, Purdue reports that $68 \%$ of their POD items circulated at least once more after their initial ILL patron usage, while only 36\% of "normally acquired" materials circulated at least once (Anderson et al., 2002, pp. 9-10).

Ward et al. (2003) published statistics taken from the University of Wisconsin-Madison and Purdue University that were similar. For UW-Madison, in a two-year period, 73\% of their ILL POD items circulated two or more times while only $6 \%$ of the items purchased for their "general collection" circulated two or more times (Ward et al., 2003, p. 208). In both reports, neither university included staffing overhead in the cost of each ILL POD title.

In their study, the University of Hong Kong found that in less than 1 year 55\% of the items purchased to support ILL requests circulated at least one other time (Chan, 2004). They estimated that the cost to purchase a book from overseas would be $\$ 58.00$, or "slightly more than double that of borrowing costs" (Chan, 2004, p. 27). After conducting their project, they discovered that the average cost was actually $\$ 66.00$, the average price per book being higher than anticipated.

The University of Southern Indiana concentrated their study on academic monographs only, quoting an average cost to purchase "an academic monograph [as] \$58.45-\$67.44," depending on library discounts (Ruppel, 2006, p.74). Ruppel (2006) felt that her pilot was still successful despite her admission that this cost was considerably higher than an ILL borrowing transaction (p. 76). She succinctly states the typical reasons a library will opt for ILL POD rather than borrowing, even though it has a more expensive up-front cost:

The institution [POD library] will regularly acquire recently published titles with a guarantee of at least one use. Many of these titles will be from interdisciplinary areas that are often missed in routine collection development. Lastly, users who do not normally have a voice in collection development will get to participate in monograph purchasing. As a result, the library's collection development policy will become more responsive to the university community's research needs (Ruppel, 2006, p. 76).

Although the University of Southern Indiana did not report any circulation statistics they reviewed many of the studies discussed in the current article which show a large portion of ILL POD titles circulate more than once. They did not discuss CPU.

The University of Minnesota Law Library followed a similar methodology limiting its ILL POD program to only items which could be purchased for less than $\$ 20.00$, including shipping (Zopfi-Jordan, 2008). Like many other institutions, the University of Minnesota Law Library routed the ILL POD item first to the patron then to their acquisitions team to add permanently to the collection. It should be noted that before giving the item to the user, the ILL staff barcoded the item, created a circulation record, checked the item out to the patron, and left a note in the item record in their integrated library system to have the patron return the item to ILL (Zopfi-Jordan, 2008, p. 391). This staff overhead workflow increases the cost of the item well above the base $\$ 20.00$ cost to purchase, to say nothing of the cost to fully catalog the item and any other tasks necessary in order to add the item to the collection later.

The University of Arkansas recently published findings after investigating the purchase of several volumes from the heavily requested Material Research Society's Proceedings (Gibson and Kirkwood, 2009). Although technically not a monographic publication, the University of Arkansas' purchasing model was similar to ILL book buying. When a patron requested an article from one of the proceedings within the past 5 years, the library purchased the entire volume for that year. Once the volume arrived, the ILL staff scanned the article requested and sent only the scanned article to the patron; they did not circulate the entire volume unless the user specifically requested to complete proceedings. Unless the entire volume was specifically requested, the volume was not cataloged until the ILL user returned the item, as with the University of Minnesota Law Library. The price to purchase from the Society was by paper, not by volume, at $\$ 20.00$ per paper. The researchers point out that this price, although comparable to the price of a mediated ILL borrowing transaction (\$17.50), still "does not include the cost of interlibrary loan staff and equipment" (Gibson and Kirkwood, 2009, p. 52). The study does not offer any circulation statistics or CPU information beyond this qualification.

Grand Valley State University in Allendale, MI, implemented their ILL POD items and examined circulation of the items over time, similar to Brucknell, Purdue, and UW-Madison. They found that $36 \%$ of all items purchased on-demand circulated more than once (Way, 2009). They also reviewed these purchases with other institutions' acquisitions using WorldCat Collection Analysis. Those titles that were held by one or more peer library had a higher average circulation, suggesting that if other libraries purchase the item, it is more likely to circulate locally. No cost-analysis was presented.

The University of Nebraska-Lincoln published results of a comparison of the circulation of items acquired traditionally with the circulation of ILL POD items (Tyler, et al., 2010). It was clear from their finding that they showed that ILL POD items do circulate more over time than traditional acquisitions (Tyler, et al., 2010, p. 170), similar to the other studies reviewed. UNL did not include overhead costs because they were not available (Tyler, et al., 2010, p. 167).

\section{Staffing overhead costs for acquisitions and cataloging processes}

Although many of the libraries above do acknowledge overhead costs, occasionally librarians see the price of a book plus shipping as the only costs to buy a book instead of borrowing it. In an opinion piece, one such library director stated that the price to purchase averaged only $\$ 10-15.00$ per item for their study, much less than the "pathetic [costs of ILL], estimated at $\$ 28$ per transaction" (Hulsey, 2003, p. 77). Yet this director either did not realize or did not admit that his $\$ 28$ figure (presumably from the ARL study reviewed in Section 1) includes the fees for ILL lending as well as ILL borrowing; the costs of a lending institution should 
be considered, but only lightly, since they have no direct effect on the borrowing library's budget. Again, in context of ILL POD, no library considers the added cost for a vendor to purchase a title from the publisher, package, and ship to a library-the analogous lending library's costs. Moreover, the director did not concede the overhead costs to add a book to the collection. The only time in which purchasing a book is less expensive than a single ILL borrowing transaction is when the library buys a cheap, used copy of a title and simply gives the book to the patron. When the book is added to the collection, though, significant costs build up related to acquisitions, cataloging, labeling, and shelving. Another librarian wisely added a cost for "processing, OCLC charges and staff time" to the books her library purchased for their ILL POD program (Campbell, 2006, p. 37). However, she added just $\$ 6.00$ to the total cost for each book to cover all of these fees, which is far too low (see Section 3).

The figure from ARL regarding the total mean cost of a borrowing ILL transaction (\$17.50) includes staffing overhead, the fee from the lending library, shipping, and other costs. ${ }^{1}$ Of this total, the mean cost of staffing consists of no less than $\$ 10.39$ (Jackson, 2004, p. 31). Thus, 59\% of the cost of an ILL borrowing transaction is staffing overhead. In an earlier study, Naylor (1997) found that the staffing cost was even higher at his institution, which accounted for $75 \%$ of his institution's total borrowing costs. Librarians who choose to follow the POD trend should consider this in their calculations. If staffing and overhead are not considered in ILL POD, the price of a book and shipping should not be less than $\$ 17.50$, but at the very least, less than $\$ 7.11$, the cost of an ILL borrowing transaction without staffing overhead included.

In order to fully estimate the cost to add a book to a library collection, this study's scope must broaden from ILL literature to include acquisitions and cataloging literature. The University of Oregon conducted a time-cost study of monographic acquisitions processes including pre-order, order maintenance, receiving, "QuickCat," and billing (Slight-Gibney, 1999). They included firm orders, standing orders, serials, domestic approvals, other approvals, gifts, and documents in their acquisitions types. Excluding serials, their average cost to acquire all of these types including overhead was $\$ 8.50$ (Slight-Gibney, 1999, p. 53). Firm order processing, perhaps the most analogous to the ILL POD process, was $\$ 9.97$ per transaction. The University of Oregon did not take into account shelf-ready books in their analysis but Slight-Gibney did suggest that the amount of overhead saved would only be displaced to new tasks such as "loading and manipulating batches of records," "quality control," and "contract initiation and maintenance" (Slight-Gibney, 1999, p. 54).

A later monographic acquisitions cost study conducted by Iowa State University reported their average total cost including overhead as \$11.31 (Fowler and Arcand, 2003). The university implemented a shelf-ready program called PromptCat in which Yankee Book Peddler approval books were sent to the purchasing library with catalog records. These records were examined briefly by acquisitions personnel to determine if the "record required any further work from the library's in-house catalogers, or if the record could be accepted as is" (Fowler and Arcand, 2003, p. 113). The university further stated that there was no time savings from this program in acquisitions since the shelf-ready quality control was handled by acquisitions staff. In fact, the PromptCat program "made the receiving process more time-consuming" (Fowler and Arcand, 2003, p. 113). Still, the user tended to get the item faster and the cataloging department saw some time benefits as well. It appears that, for Iowa State, the shelf-ready program eliminated some cataloging overhead to create more acquisitions overhead which may account for some of the difference between their $\$ 11.31$ cost and the University of Oregon's $\$ 8.50$. The cataloging cost decrease was not reported. Iowa State University did not break down the cost of each type of acquisition as University of Oregon did.

Based on these figures, this study opts to use the University of Oregon's favorable $\$ 8.50$ or perhaps more accurate but still optimistic \$9.97 over Iowa State University's general \$11.31, as an estimated cost for acquiring a title.

With regard to cataloging, Iowa State University also conducted a time-cost study of cataloging at their university as well as the acquisitions study reviewed above (Morris et al., 2000). They included staff overhead costs of "paid leave, meetings, nondivisional work, professional and administrative activities, and automation" (Morris et al., 2000, p. 71). Salaries examined included benefits (Morris et al., 2000, p. 72). The results showed that “[i]n 1997/1998 the average cost of cataloging a title at ISU was \$16.25” (Morris et al., 2000, p. 74). This figure is somewhat mitigated by the inclusion of serials in their average. The average cost to copy catalog a title was $\$ 8.87$. For a professional cataloger it was $\$ 21.63$ to catalog the same title. The University of Oregon offered related figures by stating that the "average cost of upgrading an unacceptable, member-contributed record is $\$ 9.23$. [...] Original cataloging [...] costs an average of $\$ 24.92$ per title" (Slight-Gibney, 1999).

Because both the ILL cost and the accession costs come from studies approximately eight to ten years old, inflation need not be included, since it is presumed that each cost would increase by the same rate. This study therefore designates a functional cost for firm order acquisitions as $\$ 9.97$ and these universities have also supplied a cataloging cost of $\$ 16.25$ or for copy cataloging $\$ 8.87$.

Considering the range of possible costs for acquisitions ( $\$ 8.50-\$ 11.31)$ and for cataloging $(\$ 8.87-\$ 16.25)$, the minimum cost to add a book to a collection would be $\$ 17.37(\$ 8.50+\$ 8.87)$.

\section{The BYU ILL POD program and the real costs of buying}

The Brigham Young University's (BYU) Harold B. Lee Library (HBLL) has been a member institution of the Association of Research Libraries since 1974. As of December 2009, it held 3,932,312 volumes with a circulation of 382,737 during the 2009 calendar year. The HBLL has historically estimated the total cost to add a book to its collection at $\$ 25.00$, a ball-park figure to cover

\footnotetext{
${ }^{1}$ It should be noted that ARL did not designate the mean cost of a mediated returnable (i.e., monograph) transaction. Included in the $\$ 17.50$ cost is also the mean cost to borrow a non-returnable (i.e., article). Article requests represented 56\% of the total mean cost of borrowing (Jackson, 2004, p. 61), which implies that the cost of a monographic mediated borrowing request is more than the cost of an article mediated borrowing request. Unfortunately we have no way of knowing just how much more.
} 
Table 1

Cost-per-use of ILL borrowing compared to POD over time.

\begin{tabular}{lllll}
\hline Method & CPU for 1 circ/transaction & CPU for 2 circs/transactions & CPU for 3 ${ }^{\text {a }}$ circs/transactions & CPU for 4 circs/transactions \\
\hline ILL borrowing & $\$ 17.50$ & $\$ 17.50$ & $\$ 17.50$ & $\$ 17.50$ \\
ILL POD & $\$ 57.83$ & $\$ 28.92$ & $\$ 19.28$ & $\$ 14.46$ \\
\hline
\end{tabular}

${ }^{a}$ Highlighted columns designate the minimum circs/transactions necessary to reach an estimated even cost between borrowing and buying (equilibrium).

the costs of acquisition, cataloging, labeling, and shelving; this does not include any ILL overhead for ILL POD. The HBLL uses ILLiad as its Interlibrary Loan System and its acquisitions department personnel have an ILLiad queue designated for their workflow to facilitate the ILL POD program. When an item is selected for ILL POD, it is routed through the system to that queue. At that point, the staffing cost for ILL is displaced to the acquisitions department to include extra overhead time such as searching, record management, and expedited cataloging processes. Once the item is received the request is routed systematically to the Document Delivery module and the item, after it is fully cataloged and added to the collection, is routed to the Document Delivery staff to deliver to faculty or it is routed to Circulation staff to hold for pick up for student users. Thus, an HBLL ILL POD transaction is significantly more expensive than an average ILL borrowing transaction because it impacts a multitude of other library workflows and personnel. A portion of the ILL staff overhead cost of \$10.39 is still attributed to ILL borrowing personnel since it is they who determine if the item is eligible for ILL POD and they also must manually route the request in the system to the correct acquisitions queue in ILLiad (a minor, but additional step); while not all of the $\$ 10.39$ overhead is used by borrowing staff, the transaction ends either with Document Delivery staff (and delivery is certainly more expensive than traditional ILL where a patron must come and pick up the item) or Circulation staff (who must process the request as an item on hold), perhaps justifying the inclusion of all of the $\$ 10.39$ if not more.

The HBLL has had an ILL POD program since 2005. The titles that were purchased and added to the collection for ILL support from January 2005-December 2008 were examined. The HBLL purchased and added 102 ILL POD titles during this period. The total cost to purchase all 102 titles, including shipping, was \$3,124.33. Using the individual costs for all 102 titles and averaging them together produced an ILL POD average price per title of $\$ 30.07$ for the HBLL, a number similar to those found by other universities reviewed in Section 1. If the acquisitions and cataloging overhead estimate of $\$ 17.37$ from Section 2 are added to the additional estimate of \$10.39 for ILL and Circulation staff handling (comparable with the ILL staff overhead for borrowing), the total cost to add an ILL POD book to the collection and deliver to the patron would be $\$ 26.76(\$ 17.37+\$ 10.39)$. When this was included with the average cost just to purchase a book at the HBLL (\$30.07) the total mean cost for an HBLL ILL POD accession was \$57.83 during this period $(\$ 26.76+\$ 30.07)$.

\section{Discussion}

Any library who participates in an ILL POD program should consider the added costs of staffing overhead. If the BYU estimate of $\$ 57.83$ for an ILL POD title is compared to the ILL borrowing costs of $\$ 17.50$, then it costs the HBLL over three times as much to purchase a title than to borrow it. Knowing that POD models are actually more expensive than borrowing models per transaction, cost-per-use (CPU) becomes a useful tool to help decide whether to buy or to borrow. For ILL borrowing, CPU is always a flat number: \$17.50. For ILL POD items it is more complicated. Typically, the number of times an item has been checked out is used. However, this raises some questions that the librarian must answer. Do in-house uses ${ }^{2}$ count as a circulation? Do they count as a full circulation or a partial? Does the initial use, the one which generated the ILL POD transaction, count as a circulation or only subsequent circulations?

Once those and other local questions are answered, the following numbers are useful for comparison. If an item is requested from ILL the first request costs the borrowing library on average $\$ 17.50$ to fill the request. The CPU of that item is $\$ 17.50$ since one ILL transaction gets one use by one user, the ILL patron. The second time the same work is requested from ILL, the total cost to fill all requests for that title now jumps to $\$ 35.00$, or two ILL borrowing requests, while the CPU remains constant at $\$ 17.50$. Whereas each subsequent ILL request for the same title costs the library more money while the CPU remains the same (see Table 1), the reverse is true for items that are added to the collection (see Table 2). The cost of the first use of an item added to the collection through ILL POD is $\$ 57.83$ but each subsequent use reduces the CPU while the initial cost to the library stays the same. ${ }^{3}$

It appears then that for the HBLL a fourth use makes an ILL POD purchase cost-effective with the third use costing the library about the same amount to purchase or to borrow, an equilibrium of cost.

\footnotetext{
${ }^{2}$ When an item is taken off the shelf but not checked out and is left on a library table or returned to specially designated shelves for reshelving, it is assumed a user perused it "in-house."

${ }^{3}$ Ideally, here a certain number would be added to each transaction to account for the costs to circulate an item, to reshelve it, and any other costs accumulated over lifetime ownership of a monograph. The most current report on these costs was conducted in 1986-1987 (Battaile, 1992, p. 10). The cost to circulate an item was $\$ 0.76$, including "labor and benefits, departmental cost allocation, library overhead allocation, and university overhead allocation" (Battaile, 1992 , p. 10). The cost to shelve and item was $\$ 0.15$. Inflation should be taken into account but so must a probable overall cost savings due to automation. Because of this, even if $\$ 1.00$ was added to the cost-per-use of each item it would only be an estimate, and a relatively small addition to the overall cost. As such, since the updated costs are conjecture at best 25 years later, they have been left out of the current study, hopefully balancing the cost of a monograph ILL borrowing request which is more than the average cost for all borrowing transactions, as was stated in the footnote above.
} 
Table 2

Total cost of ILL borrowing compared to POD over time.

\begin{tabular}{|c|c|c|c|c|}
\hline Method & Total cost for 1 circ/transaction & Total cost for 2 circs/transactions & Total cost for 3 circs/transactions & Total cost for 4 circs/transactions \\
\hline ILL borrowing & $\$ 17.50$ & $\$ 35.00$ & $\$ 52.50$ & $\$ 70.00$ \\
\hline ILL POD & $\$ 57.83$ & $\$ 57.83$ & $\$ 57.83$ & $\$ 57.83$ \\
\hline
\end{tabular}

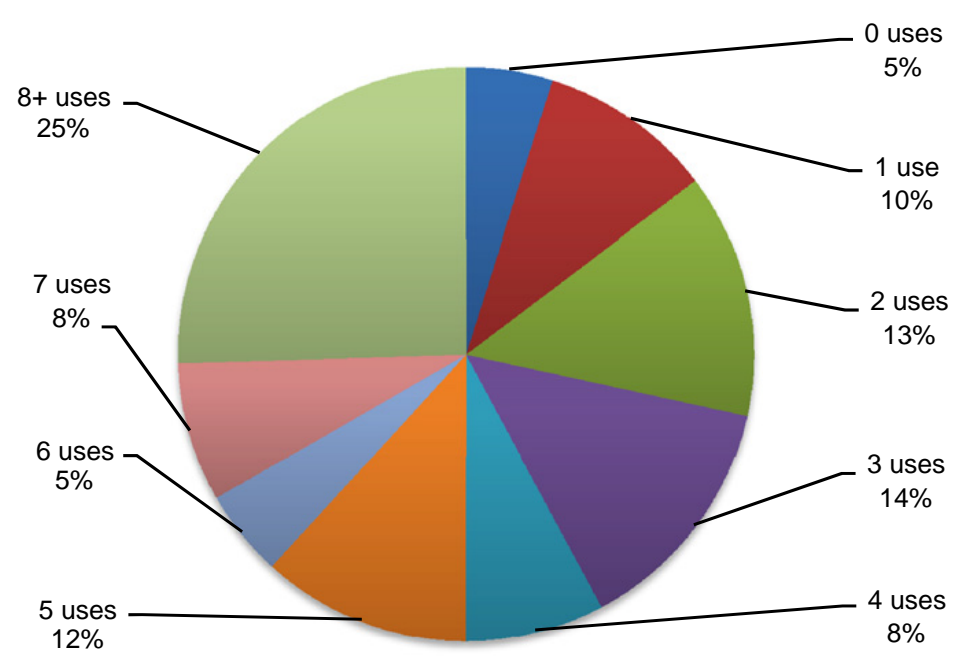

Fig. 1. Percent of ILL POD titles purchased between 2005-2008, which circulated 0-8+ times by the time of this study in summer of 2010 .

\section{The HBLL study}

The HBLL's ILL POD items purchased between January 2005 and December 2008 had a total of 728 circulations as of July 2010, including in-house uses and the initial circulations generated by the ILL patrons. 58\% of the titles purchased in that period of time circulated at least four times including the initial ILL patron use (see Fig. 1). This number is higher than Purdue's $24 \%$ and University of Nebraska-Lincoln's 27\% (Nixon and Saunders, 2010, p. 157; Tyler, et al., 2010, p. 170). Those titles were a good investment by the HBLL, based on the average cost to purchase (\$30.07). $14 \%$ of the titles were on the border, costing the library only slightly more to purchase than to borrow them. For the remaining $28 \%$ it seems that ILL might have been more cost-effective than purchasing. Purdue saw 59\% of their titles only receive two or less circulations (Nixon and Saunders, 2010); for UNL it was 55\% (Tyler et al., 2010, p. 170). Admittedly, over time titles tend to circulate more simply because they have been available longer. Brucknell University found that their earliest POD titles had a higher total circulation than those purchased more recently (Perdue and Van Fleet, 1999, p. 27).

\section{Observations}

At what point is it more cost-effective to buy instead of borrow? Brucknell University, speculating that the total cost to acquire a book might be as high as $\$ 100.00$ including overhead, suggested that after a minimum of three circulations the item would be considered a good investment (Perdue and Van Fleet, 1999, p. 23). They apparently included the lending library's costs in this estimate. The University of Hong Kong supported Brucknell University's assessment, stating that each title acquired in this ondemand model must circulate at least twice to "approach the break-even point" (Chan, 2004, p. 27). ${ }^{4}$ However, it appears from the HBLL's experience that any title that does not get four uses, including the initial ILL use, may not be worth purchasing. It could be the difference in inflation from 1999 and 2004 which is the cause of this difference. By way of extremes, in the case of very inexpensive titles $(<\$ 8.00)$, equilibrium is reached at the second use instead of the third use (see Table 3$)$; for very expensive titles ( $\$ 75.00$ ), equilibrium is not reached until the item has been used six times including the initial ILL use (see Table 4 ). $38 \%$ of the titles purchased received that minimum amount of use. Some library's low price may be another library's high price. Southern Indiana University reported that $85 \%$ of the ILL titles [purchased] are "cheap," which is defined [...] as "priced under $\$ 75.00$ " (Ruppel, 2006, p. 76), the very same cost that necessitates six uses instead of the average four. Regardless of whether $\$ 75.00$ is considered "cheap" or expensive, it still requires significant usage before it is cost-effective.

\footnotetext{
${ }^{4}$ If indeed Lawrence et al. (2001) included the cost to initially acquire a title as well as to catalog, label, circulate, shelve, reshelve, and eventually deselect it over its total life cycle, then their findings that a monograph would cost over time $\$ 343.03$, or over seven times their average cost to purchase a book ( $\$ 47.78$ ), would be extremely relevant here. Again, since the report is inconclusive on this matter the data cannot be used.
} 
Table 3

Total cost of ILL borrowing compared to POD over time for low priced items.

\begin{tabular}{llll}
\hline Method & $\begin{array}{l}\text { Total cost for 1 } \\
\text { circ/transaction }\end{array}$ & $\begin{array}{l}\text { Total cost for 2 } \\
\text { circs/transactions }\end{array}$ & $\begin{array}{l}\text { Total cost for 3 } \\
\text { circs/transactions }\end{array}$ \\
\hline ILL borrowing & $\$ 17.50$ & $\$ 35.00$ & $\$ 52.50$ \\
ILL POD for low cost to purchase $(\$ 8.00+27.76)$ & $\$ 35.76$ & $\$ 35.76$ & $\$ 70.00$ \\
\hline
\end{tabular}

Table 4

Total cost of ILL borrowing compared to POD over time for high priced items.

\begin{tabular}{|c|c|c|c|c|}
\hline Method & $\begin{array}{l}\text { Total cost for } 3 \\
\text { circs/transactions }\end{array}$ & $\begin{array}{l}\text { Total cost for } 4 \\
\text { circs/transactions }\end{array}$ & $\begin{array}{l}\text { Total cost for } 5 \\
\text { circs/transactions }\end{array}$ & $\begin{array}{l}\text { Total cost for } 6 \\
\text { circs/transactions }\end{array}$ \\
\hline ILL borrowing & $\$ 52.50$ & $\$ 70.00$ & $\$ 87.50$ & $\$ 105.00$ \\
\hline ILL POD for high cost to purchase $(\$ 75.00+27.76)$ & $\$ 102.76$ & $\$ 102.76$ & $\$ 102.76$ & $\$ 102.76$ \\
\hline
\end{tabular}

If the item is expensive, it may be better to ILL than to purchase. Very few titles receive more than five ILL requests in their lifetime. The HBLL examined its ILLiad statistics for all monographs with a publication date of 2000, totaling 3,931 requests as of May 2010. Of those requests, only nine titles were requested by five or more unique users from $2000-2009$, or $0.2 \%$ of all requests. $7 \%$ of all loan requests during this period were for a title requested by at least one other user. If the repeated requests for the same title by only one user are included the number jumps slightly to $11 \%$. The other $89 \%$ of the 3,931 loan requests were good ILL investments since they were requested only once over the ten year period. Admittedly, this does not mean that if the titles had been purchased, they never would have been checked out to another user. The numbers merely show that only one user wanted a particular title $89 \%$ of the time for that year of publication over the past decade badly enough to interlibrary loan the item.

\section{Conclusion}

What is the threshold based on purchase price? In the HBLL's experience, as can be seen from Fig. 1, 85\% of ILL POD books were checked out at least once more after the initial ILL usage ${ }^{5}$; if those items were inexpensive to purchase $(<\$ 8.00)$ the POD cost-peruse would be comparable to the cost of ILL borrowing. As a reminder, this statistic omits the lifetime $\operatorname{costs}^{6}$ to shelve and circulate and it includes all types of content, including fiction and popular nonfiction. As was seen in Section 1, some library ILL POD titles, especially those which are limited to scholarly or "academic" titles, have a much smaller chance to circulate again. Automatic purchase of any ILL loan request likely has a smaller percentage of return. Only 38\% of ILL POD books would circulate enough to "break even" if they cost more than $\$ 75.00$ (six or more times).

The library and information science profession is committed to being highly service-oriented so ILL POD has held an elevated place in library literature over the past decade. However, this desire must be balanced with budget costs. Libraries must consider how much it costs to permanently add a title to the collection (a minimum of \$27.72). Will the item get used enough to justify the increased upfront costs in staff overhead? If the cost to purchase an item is relatively low $(<\$ 8.00)$, the item would eventually "pay for itself," over time becoming cheaper than ILLing multiple copies from different libraries. If the cost is relatively high (>\$75.00), it is possible that the library will not get a full return on its investment.

More work needs to be done in this area of purchase-on-demand. As was mentioned, the figures for the cost of ILL and the costs of accession come from studies conducted almost a decade ago. These studies, although extremely valuable, predate the rise of electronic publishing, as well as the development and widespread adoption of automated interlibrary loan systems like ILLiad. Contemporary ILL cost studies which reflect the influence of e-book and e-journal subscriptions and their lending practices are also desperately needed. Moreover, the ARL study did not delineate in its mean cost the cost of a monographic request as opposed to the cost of a scanned article request. Any future cost study of ILL needs to take this difference of services into account. Similarly, studies on the cost to check in, reshelve, and house books over their lifetime need to be conducted. Another area of need is the average lifecycle of a paperback book versus that of a hardback book. All of these figures are necessary for a librarian to make the most educated decision possible regarding whether to buy or to borrow.

\footnotetext{
${ }^{5}$ This figure is likely much higher than titles purchased in a traditional way (just-in-case models). Many acquired books never receive one check out, let alone more than one. However, in some cases it is still more cost-effective to borrow multiple times than to buy-even considering the likelihood of another circulation after the initial use.

${ }^{6}$ It is unclear whether Lawrence et al. (2001) included initial acquisitions and cataloging costs (i.e., the costs to add an item to the collection) in their lifecycle cost for a monograph or if cataloging costs were only tracked once the item was fully accessioned (i.e., the cost to actually keep an item in the collection over time). Because of this ambiguity, their numbers are difficult to use in a study such as this.
} 


\section{References}

Anderson, K. J., et al. (2002). Buy, don't borrow: Bibliographers' analysis of academic library collection development through interlibrary loan requests. Collection Management, 27 (3/4), 1-11.

Battaile, C. (1992). Circulation services in a small academic library. Washington, DC: Association of Research Libraries.

Campbell, S. A. (2006). To buy or to borrow, that is the question. Journal of Interlibrary Loan, Document Delivery E' Electronic Reserve, 16 (3), $35-39$.

Chan, G. (2004). Purchase instead of borrow: An international perspective. Journal of Interlibrary Loan, Document Delivery E Information Supply, 14 (4), $23-37$.

Fowler, D. C., \& Arcand, Janet (2003). Monographs acquisitions time and cost studies: The next generation. Library Resources E Technical Services, 47 (3), $109-124$.

Gibson, T. M., \& Kirkwood, P. E. (2009). A POD pilot project at the University of Arkansas, for the proceedings of the Materials Research Society symposiums. Journal of Interlibrary Loan, Document Delivery E Electronic Reserve, 19, 47-56.

Hulsey, R. (2003). Purchase on demand: A better customer service model. Library Journal, 128 (10), 77.

Jackson, M. E. (2004). Assessing ILL/DD services: New cost-effective alternatives. Greenwood: Westport, Connecticut.

Lawrence, S. R., et al. (2001). Life cycle costs of library collections: Creation of effective performance and cost metrics for library resources. College and Research Libraries, 62 (6), 541-553.

Morris, D. E., et al. (2000). Cataloging staff costs revisited. Library Resources E Technical Services, 44 (2), 70-83.

Naylor, T. (1997). The cost of interlibrary loan services in a medium-sized academic library. Journal of Interlibrary Loan, Document Delivery E Information Supply, 8 (2), 50-61.

Nixon, J. M., \& Saunders, E. S. (2010). A study of circulation statistics of books on demand: A decade of patron-driven collection development, part 3. Collection Management, 35 (3/4), 151-161.

Perdue, J., \& Van Fleet, J. A. (1999). Borrow or buy? Cost-effect delivery of monographs. Journal of Interlibrary Loan, Document Delivery \& Information Supply, 9 (4), $19-28$

Ruppel, M. (2006). Tying collection development's loose ends with interlibrary loan. Collection Building, 25 (3), $72-77$.

Slight-Gibney, N. (1999). How far have we come? Benchmarking time and costs for monograph purchasing. Library Collections, Acquisitions, Er Technical Services, 23 (1), 47-59.

Tyler, D. C., et al. (2010). Just how right are the customers? An analysis of the relative performance of patron-initiated interlibrary loan monograph purchases. Collection Management, 35 (3/4), 162-179.

Ward, S. M., et al. (2003). Collection development based on patron requests: Collaboration between interlibrary loan and acquisitions. Library Collections, Acquisitions, E' Technical Services, 27, 203-213.

Way, D. (2009). The assessment of patron-initiated collection development via interlibrary loan at a comprehensive university. Journal of Interlibrary Loan, Document Delivery \& Electronic Reserve, 19, 299-308.

Zopfi-Jordan, D. (2008). Purchasing or borrowing: Making interlibrary loan decisions that enhance patron satisfaction. Journal of Interlibrary Loan, Document Delivery E' Electronic Reserve, 18 (3), 387-394. 